\title{
Enunciação, psicanálise e os jogos literários de Georges Perec
}

\author{
Jacques Fux (UNICAMP) \\ Humberto Moacir de Oliveira (UFMG) \\ Carolina P. Fedatto (UFMG)
}

\begin{abstract}
Resumo
As brincadeiras de esconder e encontrar objetos, assim como o jogo em que um adulto esconde o rosto com as mãos e depois o desvela vocalizando esses acontecimentos, chamaram a atenção de Freud. A psicanálise, desde então, muito tem discutido sobre a brincadeira infantil, mas pouco relaciona as descobertas freudianas sobre os jogos de esconder à teoria de que toda brincadeira representa o desejo de ser adulto, de crescer e se sentir completo, dono de si e de suas palavras. Este artigo tem como objetivo estudar as restrições e jogos utilizados na obra de Georges Perec através da teoria da enunciação e da psicanálise. Inicialmente estas contraintes perecquianas pareciam ingênuas e lúdicas somente, porém, analisando-as detalhadamente em seu contexto e em sua estrutura, encontramos diversas e potenciais interpretações.
\end{abstract}

Palavras-chave: Georges Perec. Freud. Lacan. Enunciação. Jogos.

\section{Résumé}

Les jeux de cacher et retrouver des objets, bien comme les jeux par lesquels les adultes cachent leur visage avec les mains et après les dévoile en vocalisant cet événement, ont attiré l'attention de Freud. Dès là, la psychanalyse a beaucoup discuté sur les jeux d'enfants, mais ne lie pas assez les découvertes freudiennes sur les jeux de cacher à la théorie selon laquelle tous les jeux représentent le désir d'être adulte, de grandir et se sentir complet, souverain de soi et de ses mots. Cet article a l'objectif d'étudier les contraintes et les jeux employés chez Georges Perec à partir de la théorie de l'énonciation et de la psychanalyse. Tout d'abord, les contraintes chez Perec semblaient naïves et ludiques mais, en les analysant minutieusement dans son contexte et son structure, on peut trouver diverses et potentielles interprétations.

Mots-clés: Georges Perec. Lacan. Freud. Enonciation. Jeux littéraires. 
Escrever um pequeno texto excluindo uma determinada letra, homenagear alguém utilizando seu nome para iniciar cada um dos parágrafos de um documento qualquer, descobrir palavras e frases que podem ser lidas da direita para esquerda e da esquerda para direita, encontrar relações interessantes entre os números primos, pares, ímpares são brincadeiras recorrentes que testemunham sobre a atração do homem pelos jogos de esconder e achar. Além dessas brincadeiras de linguagem, encontramos, na infância e fora dela, diversas outras brincadeiras que reproduzem as ações de esconder e achar. Em análise de uma dessas brincadeiras realizada por seu próprio neto, Freud (1920/1996) observou que a criança emitia sons que aludiam a uma oposição significante. Na ocasião, nos conta Freud, a criança emitia vocábulos que lembravam as palavras alemãs fort e da à medida que lançava seu carretel para longe de sua vista (fort: lá) e o puxava de volta (da: aqui). Essa mesma observação parece ser válida também para outro jogo de esconder muito comum na vida infantil. Trata-se do jogo de esconder e revelar o rosto, realizado, normalmente entre um adulto e uma criança de tenra idade. Também nessas ocasiões, encontramos, na maioria das vezes, o uso, por parte do adulto e depois pela criança, de verbos como sumin e achou ou algo semelhante.

Note-se que o jogo do neto de Freud só se efetiva através da emissão de sons pelo bebê, sons que são interpretados pelo adulto como sendo advérbios dotados de um sentido locativo, isto é, elementos que remetem à enunciação e participam da atualização de um enunciado em relação à instância do discurso e dos objetos do mundo que referem. Em sua clássica análise sobre os pronomes e os dêiticos, Benveniste mostra que há uma distinção essencial em qualquer língua entre o en e o não-eu que fundamenta o duplo funcionamento subjetivo e referencial do discurso. Operada por índices especiais constantes nas línguas, os chamados dêiticos ou embrayers realizam uma dupla oposição: de um lado, entre a estrutura de alocução pessoal exclusivamente inter-humana: eu-tu (que constitui, por sua vez, uma série de indicadores ligados à enunciação, como: este-esse, aqui-ali, etc.) e, de outro, opondo as pessoas à não-pessoa: eu-tu / ele e referindo-se não mais à presente instância de discurso, mas aos objetos "reais", aos tempos e lugares históricos: este-esse / aquele, aqui-ali / lá. Essa oposição entre eu (aqui, agora) e não-eu (lá, então) efetua a operação da referência, sustentando a possibilidade de falar sobre alguma coisa, sobre o mundo, sobre o que não é a alocução, sobre o não-eu. Dessa forma, o falante é incluído em seu discurso, o en se coloca socialmente enquanto participante, desdobrando uma rede complexa de re- 
lações espaço-temporais que determinam os modos de enunciação (BENVENISTE, 1968, p. 101). Outro ponto interessante a ser discutido a partir da enunciação do fort-da na brincadeira infantil é sua implicação na aquisição da linguagem pela criança. A passagem do infans, aquele que não fala, a sujeito falante se dá porque o adulto atribui sentido à fala da criança, chamando-a ao simbólico. É preciso considerar ainda que a língua antecede o infans na cultura e, por isso, determina o percurso da aquisição da linguagem. Não se trata de uma simples aprendizagem, mas de uma captura pela língua que:

considerada sua anterioridade lógica relativamente ao sujeito, o precede e, considerada em seu funcionamento simbólico, poder-se-ia inverter a relação sujeito-objeto, conceber a criança como capturada por um funcionamento linguístico-discursivo que não só a significa como lhe permite significar outra coisa, para além do que a significou (LEMOS, 2002, p. 55).

Embora o diálogo entre o adulto e o bebê seja radicalmente assimétrico, a começar pelo fato de que inicialmente só o adulto fala e, sobretudo, fala pela criança, ele é fundamental, pois transmite ao infans uma "vocação humana". Essa expressão do psicanalista Didier-Weil sintetiza a equivocidade da voz que, "ao passar a fala, passa também à criança a sua música, transmitindo-lhe uma vocação ambígua: 'está ouvindo a continuidade musical de minhas vogais e a descontinuidade significante das minhas consoantes?"” (apud CASTRO, 2005). Esse processo de entrada no simbólico, mesmo que o objetivo de falar encontre exceções, é uma imposição: para ser bumano não há como ser diferente. Tanto que Benveniste afirmou em um artigo sobre as relações entre língua e sociedade que "nada pode ser compreendido - é preciso se convencer disto - que não tenha sido reduzido à língua.” (1968, p. 99). Nada. Nem mesmo o sujeito. E ser reduzido à língua tem a dupla função de entrada na história e no simbólico. Dito isto, como podemos relacionar e estudar as brincadeiras infantis com os jogos de linguagem e com a biografia de Perec?

Os jogos e as restrições, tanto os literários em Perec, quanto os de esconder em geral, muito se assemelham, mas há, certamente, especificidades. Em um desses jogos de esconder, por exemplo, diferente da brincadeira observada por Freud, quem exerce o papel ativo de esconder é o adulto que brinca com a criança e é o adulto também quem enuncia verbos como sumiu e achou, tão comuns nas brincadeiras em língua portuguesa e apresentam o mesmo paralelismo da oposição descrita por Freud entre o fort e o da. Interessante é analisarmos o que está em jogo nessas escolhas lexicais. O antônimo clássico de sumir é aparecer, não achar, que seria oposto a perder. Sumir (desaparecer) e apare- 
cer, de um lado. Esconder (perder) e achar, de outro. O primeiro par de contrários se afina na medida em que se trata de verbos que selecionam sujeitos que serão o tema da ação verbal. Já o segundo conjunto se caracteriza justamente por selecionar sujeitos causadores do evento. Mas a dualidade que se enuncia na vocalização do adulto nas brincadeiras com a criança é muitas vezes assimétrica em relação à agentividade, os pares encontrados com maior frequência são sumir e achar ou esconder e aparecer. De qual sintoma essa dissimetria seria o rastro?

As brincadeiras infantis que envolvem o esconder e o achar são repletas de significado e demandam, por isso, interpretações consequentes com os diversos aspectos que as constituem: o psíquico, o linguístico e o poético. A pergunta que colocamos diante desse entrelaçamento é: como brincadeiras infantis e jogos literários se relacionam na obra de Georges Perec e como podem ser estudadas e interpretadas pela teoria psicanalítica do brincar e pelos estudos linguísticos de caráter histórico-enunciativo? Do ponto de vista da linguística, da psicanálise e da literatura perguntamos: o que desejaria esconder e revelar Georges Perec?

\section{Jogos e restrições}

A primeira restrição que o homem encontra em sua relação com o mundo é a obrigação de empregar as formas da língua, ou seja, unidades de sentido numerosas, mas sempre em quantidade finita, através de um conjunto de regras que lhe são inatingíveis e que fixam as condições sintáticas nas quais essas formas podem e devem aparecer, permitindo um número incalculável de enunciações e sentidos (BENVENISTE, 1968, p. 99). A entrada no simbólico não é, repetimos, uma escolha, assim como a permanência nele não deixa de ser uma imposição e, ao mesmo tempo, uma abertura e um jogo.

Falando dos jogos infantis, encontramos um grande número de brincadeiras que, como as citadas acima, incluem o ato de esconder e aparecer. Desde as brincadeiras, aparentemente mais remotas, de esconder o rosto, até a típica brincadeira do esconde-esconde quando as crianças ou adolescentes em grupos brincam de encontrar umas às outras. Permeando esses dois tipos de brincadeiras, temos ainda o célebre jogo do fort da analisado por Freud, quando a própria criança exerce tanto o papel de fazer perder o objeto quanto o papel de fazê-lo aparecer.

Fato curioso nessas brincadeiras é a separação que podemos propor entre aquelas em que a criança anseia pelo encontro 
do objeto escondido ou desaparecido e aquelas em que a criança anseia por não ser encontrada ou por ludibriar o outro o maior tempo possível. A maioria delas se enquadra na categoria dos jogos em que a criança anseia por encontrar o objeto ou, no caso de ser ela mesma o objeto escondido, em ser encontrada por um adulto. Mesmo nos jogos em que a criança age ativamente se escondendo ou escondendo o objeto, o desejo de ser descoberto ou de encontrar o objeto, como no caso do carretel, parece estar mais evidente do que o desejo de enganar ou de permanecer escondida, haja vista as crianças não se incomodarem muito em os adultos notarem onde e como elas estão se escondendo. Somente mais tarde, quando já maduras, é que as crianças parecem realmente se importar em permanecer escondidas por um maior intervalo de tempo.

Podemos conjecturar que Georges Perec se coloca na mesma posição da criança que brinca de se esconder quando escreve: "Uma vez mais, fui como uma criança que brinca de esconde-esconde e não sabe o que mais teme ou deseja: permanecer escondida, ser descoberta.” (PEREC, 1995, p.14). É muito interessante para o nosso debate a observação do escritor, pois se é a própria criança quem se esconde poderíamos supor que seu maior desejo fosse não ser encontrada ou ao menos ludibriar o outro durante o máximo de tempo possível. Em alguns casos, pode até ser que esse desejo de ludibriar se confirme, mas o escritor indica que o anseio de não ser encontrado divide espaço com outro desejo, o de ser descoberto, ou com um temor, o de não ser descoberto e sumir. Em outras palavras, poderíamos dizer que na maioria dos jogos que propomos pesquisar, a criança, mesmo que ativamente escondida, apresenta um claro desejo de ser descoberta que só pode ser fruto, como indicam Perec e as relações linguísticas entre os verbos em questão, de um temor, o temor de não ser jamais encontrada, de perder o controle sobre o ato de esconder e se tornar o sujeito não agentivo de um verbo inacusativo ${ }^{1}$ (a criança sumiu, desapareceu, foi embora). Nesse sentido, a enunciação de pares verbais semanticamente contrários e cruzados em relação à agentividade, como sumiu-achou, esconder-aparecer, funciona como um conforto ou uma promessa de que no final tudo dará certo: 0 objeto sumiu, mas você 0 achou ou você se escondeu/escondeu o objeto, mas ele apareceu novamente. A dissimetria dos pares verbais é justamente o signo de que há propriedades estruturalmente comuns, dizem os linguistas, entre o objeto de um verbo transitivo e o sujeito dos verbos inacusativos. Neste caso, podemos dizer que a presença ou a ausência da agentividade na ação verbal é um indício da tensa subjetivação da criança ao imperativo da falta e ao desejo de controle.

Assim, inicialmente, Perec esconde seus jogos e restrições. Seus leitores e amigos vão descobrindo e revelando lentamente essas regras secretas, apesar de nunca de fato descobrirem
${ }^{1}$ Os verbos podem ser divididos em relação ao número de argumentos que selecionam. Segundo esse critério há, basicamente, dois tipos de verbos: os transitivos, que selecionam ao menos dois argumentos na posição de sujeito e objeto, e os intransitivos, que possuem apenas um argumento na posição de sujeito. Entretanto, estudos em gramática relacional (Perlmutter, 1978) e gerativa (Burzio, 1986), apontam para uma subdivisão mais refinada no interior da categoria dos intransitivos motivada tanto por aspectos de ordem semântica (agentividade), quanto de ordem estritamente sintática (atribuição de caso acusativo). Observouse que há verbos tipicamente intransitivos, também chamados de inergativos, isto é, que apresentam um só argumento em posição de sujeito agente ( $\mathrm{x}$ achou), e verbos descritos como sendo inacusativos, ou seja, selecionando um argumento que aparece na posição de sujeito, mas que seria gerado, em estrutura profunda, no interior do sintagma verbal, como um objeto (x sumiu). Isso quer dizer que o sujeito de um verbo inacusativo se comporta de forma parecida ao objeto dos verbos transitivos, ou seja, como sendo afetado pela ação do verbo, e não como sendo seu causador. 
${ }^{2}$ Um texto de tamanho indeterminado, cujas letras podem ser lidas da direita para esquerda ou ao contrário, como se vê em "AMOR - ROMA".

${ }^{3} \mathrm{Um}$ texto que exclui uma ou mais letras do alfabeto.

${ }^{4}$ Jogo chinês conhecido por sua complexidade e pelo grande número de combinações possíveis.

${ }^{5}$ Transposição de letras de palavras ou de frases, a partir da qual uma nova palavra ou frase é formada. todas, como escreveu seu amigo Italo Calvino: “embora tenha frequentado Perec durante os nove anos que dedicou à elaboração do romance, só conheço algumas de suas regras secretas" (CALVINO, 2003, p.136). Seus segredos correriam, pois, o risco de desaparecer ou de permanecer sempre escondidos?

\section{Psicanálise}

Freud se ocupa da função do brincar em vários momentos de sua obra, tecendo comentários e analogias diversas. Comparando a brincadeira à atividade artística, Freud em "Escritores criativos e devaneios", texto de 1908, afirma que:

\footnotetext{
O escritor criativo faz o mesmo que a criança que brinca. Cria um mundo de fantasia que ele leva muito a sério, isto é, no qual investe uma grande quantidade de emoção, enquanto mantém uma separação nítida entre o mesmo e a realidade. (FREUD, 1908/1996, p.135)
}

Ao escrever sobre o escritor criativo, Freud poderia muito bem estar fazendo uma referência direta à Georges Perec e sua capacidade de escrever partindo de regras, jogos e restrições formalmente construídas. Assim Perec trabalha exaustivamente (e criativamente) com suas fantasias literárias: palíndromos, ${ }^{2}$ lipogramas, ${ }^{3}$ xadrez, go, ${ }^{4}$ lógica, anagramas. ${ }^{5}$ Investindo grande quantidade de emoção e trabalho duro, escreve um livro inteiro sem o uso da letra e: La disparition. Cria possivelmente o maior palíndromo conhecido na época, composto por cinco mil palavras, Palindrome (PEREC, 1973b, p.97-102). Escreve um conto chamado What a Man! (1996), no qual discute a história de dois personagens, Andras MacAdam e Armand d'Artagnan, no qual somente a vogal $a$ é permitida.

Em muitos momentos, Perec escreve que a literatura (assim como a arte do puzzle) é um jogo que se joga a dois, por exemplo, criança-criança, criança-adulto, leitor-autor, na qual cada forma de leitura foi pensada anteriormente pelo autor, ao menos em seu imaginário, fazendo-o crer, assim, que controla todas as suas possibilidades. Porém, ele próprio discorda e refuta, o tempo todo, esse jogo entre autor e leitor. Por mais matemático e estruturado que o projeto literário seja, trata-se ainda, e sobretudo, de linguagem e quando a obra alcança o público, leitura e recepção não estão mais nas mãos do construtor de puzそles. $\mathrm{Na}$ verdade nunca estiveram, a não ser na imagem que o autor faz de si mesmo como origem de seu dizer e arquiteto do texto. A interpretação dos sentidos do texto literário não 
escapa somente ao leitor; mesmo o escritor, por seu próprio inconsciente e pela falha que estrutura a linguagem, não tem tanto controle assim sobre os efeitos das formas linguísticas que coloca em funcionamento.

De forma lúdica, Perec trabalha problemas importantes dentro da literatura como o projeto de totalidade e esgotamento. Tentando descrever tudo o que se passa em uma praça em Paris, compõe o livro Tentative d'épuisement d'un lieu parisien (2003a); com o intuito de pensar em todas as possibilidades de se pedir um aumento ao chefe, escreve $A$ arte $e$ a maneira de abordar seu chefe para pedir um aumento (2010). Entretanto, Perec está ciente da limitação, e através dessa tentativa absurda da totalidade e do esgotamento, critica qualquer projeto que tente abarcar o todo.

Essa crítica pode ser estendida ao conceito de leitor ideal: por mais versado e idealizado que o leitor perecquiano seja, a totalidade e o esgotamento de seus mecanismos ficcionais são inatingíveis. E justamente por se colocar a si mesmo e a seus leitores diante de tantas restrições, é que Perec se separa da realidade ou se aproxima do real através da escrita. Pois, importando-se mais com a operação lógica de sua escrita do que com suas representações simbólicas, faz com que os significantes de seu texto funcionem como o que na obra lacaniana conhecemos por letra. A letra, para Lacan (1971/2003), é o que o significante tem de marca, é rasura que nada representa. Diferentemente do significante, que representa, que faz cadeia e que ajuda a tecer o simbólico, a letra se detém. Ela delineia um litoral entre o simbólico e o real, desenhando a borda do furo no saber. É litoral que vira literal. Litoral este que se situa entre centro e ausência, entre saber e gozo. A letra, portanto, se encontra fora do jogo representativo, não representa; pelo contrário, se detém em sua própria materialidade. Não forma cadeia, marca. Não engendra um sentido, faz furo. $\mathrm{O}$ texto de Perec parece situar-se nesse litoral entre o simbólico da representação e a possibilidade do real da lógica matemática.

Insistindo no paralelo entre os jogos infantis e a arte, Freud (1942/1996) afirma ainda que para a plateia de um teatro, participar do jogo dramático funciona como o equivalente de uma brincadeira infantil. Ou seja, não só o artista, mas também o público, faz do jogo artístico um substituto do brincar infantil e usa essas atividades para satisfazerem seus desejos dentro de limites considerados culturalmente normais. Da mesma maneira que no teatro, na literatura autor e leitor assumem semelhante papel.

Essa relação é muito próxima à posição do leitor, principalmente na obra de Perec. De acordo com Jacques Derrida "um texto só é um texto se ele oculta ao primeiro olhar, ao primeiro encontro, 
${ }^{6}$ Sugestão de Lacan (1969/1970) ao enigma da esfinge. a lei de sua composição e a regra de seu jogo. Um texto permanece, aliás, sempre imperceptível. A lei e a regra não se abrigam no inacessível de um segredo, simplesmente elas nunca se entregam, no presente, a nada que se possa nomear rigorosamente na percepção" (DERRIDA, 1991, p.7). Dessa forma os textos construídos pelas contraintes não se entregam ao primeiro olhar, suas regras e sua composição escondem e ludibriam o leitor.

Inicialmente os jogos de esconde-esconde de Perec não são revelados. É apenas após a publicação póstuma de seu Cabier de charges (1993) e de diversas entrevistas, que suas invenções e restrições começam a ser reveladas. Sua obra, constituída por contraintes, pode ser considerada uma forma contemporânea de enigma (esconde-esconde), diante do qual a posição do leitor se torna ainda mais repleta de potencialidade. Novamente podemos recorrer à obra lacaniana e perceber como o arranjo textual de Perec se aproxima do real e com isso fortalece sua potencialidade. O ensino de Lacan nos indica que a estrutura do enigma é expressa em termos próximos aos da estrutura da verdade. Se a verdade não pode ser dita por inteiro, mas sempre ao nível de um semi-dizer, o enigma se apresenta, também, nessa mesma dimensão. Mas, se o enigma é um semi-dizer, o que é que ele diz e o que é que ele deixa por dizer? No livro XVII do Seminário de Lacan (1969/1970) vemos que o enigma encontra sua expressão, sua semi-verdade, ao lado da enunciação que deverá ser convertida em enunciado. No exemplo clássico de enigma que encontramos na tragédia de Édipo, a enunciação se expressa através do animal com quatro patas matinais, duas patas vespertinas e três patas noturnas. A conversão dessa enunciação em enunciado é o trabalho do qual Édipo se encarrega. Que a enunciação seja convertida em "animal homem" ou no próprio Édipo ${ }^{6}$ não é o que mais importa. Afinal, a verdade não pode mesmo ser dita por inteiro, o que confere ao enigma uma impossibilidade de respostas ou, o que seria quase equivalente, uma infinidade de respostas. Esse parece ser o destino do texto de Perec, suscitar infinitas respostas para improváveis perguntas.

Se a escrita torna-se um enigma, a leitura é participação na criação, é um diálogo com o texto e o autor, concepção na qual se inserem os leitores perecquianos. A obra de Perec, assim como um jogo de esconde-esconde, é uma inovação já que é necessária a intervenção concreta do leitor para que o jogo aconteça. Ao mesmo tempo, sabemos que esse leitor necessário e ativo não irá alcançar, de fato, toda a potencialidade da obra, devido ao grande número de combinações que possibilita.

Perec nos apresenta e discute sempre o jogo leitor-autor existente em toda obra, ao mesmo tempo em que revela a impossibilidade de uma programação exata da recepção de qual- 
quer obra literária, mesmo que ela parta de procedimentos matemáticos. De acordo com Compagnon:

Baseado no leitor implícito, o ato da leitura consiste em concretizar a visão esquemática do texto, isto é, em linguagem comum, a imaginar os personagens e os acontecimentos, a preencher as lacunas de narrações e descrições, a construir uma coerência a partir de elementos dispersos e incompletos. A leitura se apresenta como uma resolução de enigmas (conforme aquilo que Barthes chamava de "código hermenêutico", ou de modelo cinegético, citado a propósito da mimèsiss). Utilizando a memória, a leitura procede a um arquivamento de índices. A todo momento, espera-se que ela leve em consideração todas as informações fornecidas pelo texto até então. Essa tarefa é programada pelo texto, mas o texto a frustra também, necessariamente, pois uma intriga contém sempre falhas irredutíveis, alternativas sem escolha, e não poderia haver realismo integral. Em todo texto, existem obstáculos contra os quais a concretização se choca obrigatória e definitivamente (2006, p.152).

Para Perec a leitura é também a resolução de enigmas, em cuja descoberta os conhecimentos matemáticos podem ajudar, o erro e a falha existem e são, também, incorporados nessa literatura, aumentando ainda mais sua potencialidade. Em obras como A vida modo de usar, além de caçador e detetive, o leitor é ainda viajante, já que sua leitura, "como expectativa e modificação da expectativa, pelos encontros imprevistos ao longo do caminho, parece-se com uma viagem através do texto" (COMPAGNON, 2006, p.152). Esses encontros imprevistos, no livro, são possíveis graças às contraintes matemáticas e, também, às falhas delas resultantes. Nesse jogo, por mais que o uso de restrições seja determinante o leitor é livre, podendo aceitar buscar, identificar e reconhecer esses artifícios ficcionais ou deixá-los passar e encontrar outros sentidos para a obra.

Em Freud, o que parece ser compartilhado tanto para a arte quanto para o brincar é, de fato, a fantasia. Em 1911, Freud escreve "Formulações sobre os dois princípios de funcionamento mental" onde destaca um dos elementos-base de sua teoria, o princípio de prazer. O princípio de prazer, fundamento tanto para o brincar quanto para a atividade artística, é o mecanismo mental que leva o ser humano, desde os períodos mais primórdios de sua existência, a buscar o prazer independentemente da realidade. Porém, visto que um ser vivo que se encontrasse imerso apenas nessa situação de busca intensa de prazer e desprezo da realidade jamais poderia manter-se vivo por muito tempo, o aparelho psíquico teve de tomar outra atitude perante a vida e se guiar não apenas pelo que é sentido pela mente como prazer, mas também como real. É importan- 
te frisar que o real ao qual Freud se refere aqui se distingue do real lacaniano que tratamos acima, o real como impossível de ser simbolizado, como o inassimilável pelo significante. Assim, o princípio de prazer incluiria, para se livrar de novos desapontamentos, um outro princípio, o princípio de realidade. A grande contribuição que essa teoria oferece ao estudo das brincadeiras infantis é justamente no que se refere à fantasia, pois, como observa Freud, nosso aparelho mental apresenta sérias dificuldades em renunciar a um prazer uma vez obtido e como o princípio de prazer se manifesta com muito mais liberdade quando independe da realidade, o aparelho mental se apega a essa forma de obtenção de prazer e a conserva lado a lado com as outras funções do organismo psíquico. Assim é que uma parte de nossas atividades de pensamento é liberada do teste de realidade e permanece subordinada somente ao princípio de prazer. Nas palavras do próprio Freud: "Esta atividade é o fantasiar, que começa já nas brincadeiras infantis, e, posteriormente, conservada como devaneio, abandona a dependência de objetos reais." (1911/1996, p.241).

Temos então uma definição do brincar que se sustenta principalmente no princípio do prazer, conservado na fantasia, e em um dos principais desejos infantis, o de ser um adulto, o que, como já dissemos, muito contribui para a constituição subjetiva. Essa primeira definição de Freud nos ajuda a compreender muito incompletamente uma poesia como a de Perec, pois embora o autor se aproxime da infância em seus jogos enigmáticos, não parece estar essa aproximação sustentada no princípio do prazer, ou apenas nele, algo além do princípio do prazer parece reivindicar um lugar na obra perecquiana, afinal, como foi dito, seu texto se encontra muitas vezes mais perto do real do trauma do que do simbólico e do imaginário da fantasia. Nessa perspectiva é que as colaborações freudianas à teoria do brincar após 1920 parecem estar em posição mais apropriada para o estudo da obra de Perec.

\section{Além do princípio do prazer e a repetição em Perec}

Georges Perec nasceu em 1936, na cidade de Paris, onde viveu a maior parte de sua vida, e morreu em Ivry, 46 anos depois. Seu pai lutou na Segunda Guerra Mundial, sendo morto em 1940, e sua mãe morreu em Auschwitz. Perec, órfão aos seis anos, foi criado por parentes próximos. Esse evento mar- 
cou profundamente sua obra; "evento que justamente resiste à representação" (SELIGMANN-SILVA, 2003, p.373). Assim, a partir de suas restrições e jogos de esconder, Perec inaugura uma nova forma de tentar representar o que resiste. Em La disparition, por exemplo, Perec subtrai a letra $e$, a mais frequente no francês e alicerce de seu nome. A supressão de uma letra fundamental em sua escrita literária pode ser interpretada como sendo o signo de uma privação fundante, que se manifesta justamente como a borda no furo de um saber. o de ter sido impedido de conviver com os pais, fazendo-o transitar, pela letra - ou pela falta dela, entre o simbólico e o real. Também em $W$ ou a memória da infância, Perec discute através de uma autobiografia ficcional, a relação de sua vida, como um filho do nazismo, e um mundo imaginado que permitiu democraticamente a existência da Shoah. A estrutura apresentada em La disparition (e na obra espectral Les Revenentes) elabora formalmente os problemas colocados pela literatura de testemunho ${ }^{7}$, mas o faz justamente de forma escondida, eclipsando a lacuna na trama ficcional e/ ou significante.

Perec trabalha, assim, com quatro grandes categorias que não podem ser separadas: "A primeira dessas interrogações pode ser classificada como 'sociológica': como observar o cotidiano; a segunda é de ordem autobiográfica; a terceira lúdica, retoma meu gosto pelas contraintes, ${ }^{8}$ as proezas, os jogos e todos os trabalhos do OULIPO; e a quarta concerne ao romanesco, ao gosto pelas histórias e peripécias" (PEREC, 1985, p.10). O esgotamento também faz parte de seu trabalho e de seus objetivos literários. Seria esse trabalho fruto de um trauma? Por isso o estudo sob o viés psicanalítico dos jogos. "A história do trauma é a história de um choque violento, mas também de um desencontro com o real. A incapacidade de simbolizar o choque determina a repetição e a constante 'posterioridade', ou seja, a volta après-coup da cena” (SELIGMANN-SILVA, 2003, p.49). Em La disparition, Perec dialoga com a impossibilidade de simbolizar o real e da tradução. ${ }^{9}$ Esse problema acerca da tradução, construído em Perec através do seu lipograma, poderia ser comparável à "A tarefa do tradutor" de Benjamim? Como acreditar nos testemunhos e nas notícias que começam a circular sobre os campos de extermínio em 1942? Como conceber um livro sem a letra $e$ ? Como traduzir um livro sem a letra mais frequente do alfabeto francês? O real aqui se manifesta na negação; “daí a resistência à transposição (tradução) do inimaginável para o registro das palavras" (SELIGMANN-SILVA, 2003, p.50). O lipograma (contrainte explícita) é pensado anteriormente ao desenvolvimento do texto como "o indizível não está escondido na escrita, é aquilo que muito antes a desencadeou" (PEREC, 1995, p.54). O desejo de crescer e a busca do prazer se manifestam em Perec. Assim La disparition é uma nova forma de discutir
${ }^{7}$ Segundo Seligman-Silva o problema seria que "na literatura de testemunho não se trata mais de imitação da realidade, mas sim de uma espécie de "manifestação" do "real". É evidente que não existe uma transposição imediata do "real" para a literatura: mas a passagem para o literário, o trabalho do estilo e com a delicada trama de som e sentido das palavras que constitui a literatura é marcada pelo "real" que resiste à simbolização” (2003, p.386-7).

${ }^{8}$ Uma contrainte pode ser entendida como uma restrição inicial imposta à escrita de um texto ou livro, sendo as mais básicas de caráter linguístico. Existem, porém, outras restrições artificiais, que podem ser de caráter matemático, como as sugeridas pelos fundadores do grupo francês OULIPO, criado em 1960 pelo matemático François Le Lionnais e pelo escritor, enciclopedista e matemático amador Raymond Queneau.

\footnotetext{
${ }^{9}$ Apesar da impossibilidade de se traduzir La Disparition, há algumas traduções como no espanhol El secuestro e no inglês A void. Esse paradoxo de se traduzir o intraduzível pode ser relacionado com o paradoxo proposto por Primo Levi em Os afogados e os sobreviventes. Para Levi, o verdadeiro testemunho seria dado pelo próprio muçulmano, embora seja impossível testemunhar (Agamben, discutindo o paradoxo de Levi, tenta mostrar o verdadeiro testemunho do muçulmano em $O$ que resta de Auschwitz).
} 
${ }^{10}$ Referência ao livro de Jacques Derrida Demeure. os conceitos da escrita de testemunho. Utilizar uma contrainte para trabalhar com a falta, com a limitação, com a intraduzibilidade e com a impossibilidade de narrar o que de fato aconteceu, o que de fato foi sentido e vivenciado. "A linguagem é antes de mais nada o traço - substituto e nunca perfeito e satisfatório de uma falta, de uma ausência" (SELIGMANN-SILVA, 2003, p.48). Assim escreve Perec:

Eu escrevo [...] porque eu fui um entre outros. Eu escrevo sem E, eu escrevo sem eles, E e eles estão inseparavelmente ligados, ausentes/presentes, eles presentes no livro como na letra tabu sempre aqui em filigrana, jamais escrito e sempre convocado pela perífrase, metáfora, comparação ou metonímia. Breve, o lipograma, ou como dizer (como se calar?) o indizível (PEREC apud MAGNÉ, 1999, p.41).

A literatura de Perec é obsessiva. Ele não quer e não pode esquecer. Ele deve testemunhar sua vida, sua infância e sua criação para se demeurer ${ }^{10}$. O testemunho, a lembrança, a literatura, a invenção e a escrita são a busca do seu eu, do seu je. Il faudrait dire je. Il voudrait dire je. Mais, quel "je"? (PEREC apud LEJEUNE, 1991, p.11).

Eu sou en é uma fórmula tautológica em que me represento igual a mim mesmo para o teatro da consciência (PÊCHEUX, 1997, p. 154). Benveniste nos diz que, em termos linguísticos, en é quem enuncia o presente que me contém, é EGO quem diz EGO e é em torno do ego que se determinam as relações com o outro (eu-tu), com o referente (eu-tu/ele) e com a temporalidade (1970, p. 85). Esse ato individual de utilização que coloca a língua em funcionamento é, justamente, a definição benvenistiana da enunciação (BENVENISTE, 1970, p. 82). Daí procede a instauração da categoria do presente e dela nasce a categoria do tempo. O presente é essa presença no mundo que só a enunciação torna possível, porque "o homem não dispõe de nenhum outro meio de viver o 'agora' e de torná-lo atual senão realizando-o pela inserção do discurso no mundo", empregando a língua, enunciando (1970, p. 85). Esse presente coextensivo à presença do $e u$ se delimita "entre o que vai se tornar presente e o que já não o é mais” (1970, p. 86).

Lembrar é afirmar o que se cala e o que não quer falar. "Eu não quero esquecer. Talvez esse seja o núcleo de $W$ ou memória da infância: guardar intacto, repetir a cada ano as mesmas lembranças, evocar as mesmas imagens, os mesmos minúsculos eventos, agrupar tudo numa memória soberana, desmesurada" (PEREC apud LEJEUNE, 1991, p.179). Assim como "qualquer fato histórico mais intenso permite - e exige! - o registro testemunhal tanto no sentido jurídico como também no sentido de 'sobrevivente"' (SELIGMANN-SILVA, 2003, p.9), Perec o 
faz de forma ficcional e estrutural em sua obra e através de suas contraintes. Já que a Shoab tentou apagar a memória da História e os lager foram instrumentos da eliminação física e memorial da existência de muitos, Perec, através de enunciações particulares, deixa rastros de seus pais e da memória das coisas. O seu testemunho, assim como o dos sobreviventes da Shoah, é inexato, incompleto, falseado e fictício. Sua obra discute essencialmente a visão de testemunho descrita por Derrida: "o testemunho tem sempre parte com a possibilidade ao menos da ficção, do perjúrio e da mentira. Eliminada essa possibilidade, nenhum testemunho será possível e, de todo modo, não terá o sentido de testemunho" (DERRIDA, 1998, p.28). Assim a literatura de Perec tem a capacidade de se relacionar com o "mundo fenomênico", extraliterário, seja através de suas contraintes, seja através de suas lembranças de infância e de suas marcas através da escrita.

Em outros textos, como Penser/Classer e Espèces d'espaces, Perec dá indícios de sua obsessão pela possibilidade de manisfestação do real nos mínimos episódios, nos simples fatos do cotidiano. Em Espèces d'espaces, Perec questiona os estratos que sustentam a oposição binária entre discursos ficcionais e referenciais, e entre narração e descrição. Assim mostra muito bem que nem tudo é literatura/ficção. Ao empreender o que parece ser a simples descrição e nomeação dos espaços, Perec coloca em questão as evidências da descrição, da narração, da referência. O objeto da descrição, por vezes, é o próprio espaço do texto, o que força o leitor a uma revisão da própria noção de descrição, uma vez que nesses momentos não há objeto referencial ou extraliterário a ser descrito: o que se descreve é o espaço mesmo onde a descrição está acontecendo. Perec preenche, assim, o espaço "página" de todas as formas possíveis, muitas vezes de modo lúdico, em outras atribuindo à escrita funções simples, porém inusitadas. Ele escreve para "se percorrer", fazendo-o horizontalmente através de citações e escrevendo à margem da folha. O universal, portanto, reside no mais fragmentário e a obra de Perec é capaz de "relacionar o seu passado com o trauma o que implica tratar desse passado de um modo mais complexo que o tradicional" (SELIGMANN-SILVA, 2003, p.76). Seu passado passa a ser sua obra e seu "testemunho não pode ser confundido nem com o gênero autobiográfico nem com a historiografia - ele apresenta uma voz, um 'canto (ou lamento) paralelo', que se junta à disciplina histórica no seu trabalho de colher os traços do passado" (SELIGMANN-SILVA, 2005, p.79).

Perec discute de forma ficcional conceitos em relação ao testemunho já que "a literatura de testemunho apresenta um modo totalmente diverso de se relacionar com o passado. A sua tese central afirma a necessidade de se partir de um determinado presente para a elaboração do testemunho. A concepção linear do tempo é substituída por uma concepção topográfica: 
a memória é concebida como um local de construção de uma cartografia, sendo que nesse modelo diversos pontos no mapa mnemônico entrecruzam-se, como em um campo arqueológico ou em um hipertexto" (SELIGMANN-SILVA, 2005, p.79).

Algumas conjecturas podem ser feitas acerca das relações entre as contraintes e a Shoah na obra de Perec. O escritor discute e trabalha com a estrutura da língua e da linguagem. A estrutura política da época permitiu a ascensão de Hitler e do partido nazista. Perec impôs seus palíndromos e lipogramas imaginando (será?) que se a História (com H maiúsculo, como ele frisa) pudesse ser escrita de trás para frente, teríamos repetido as mesmas catástrofes da História escrita de frente para trás. A História seria palindromática e fechada? A História estaria engessada em alguma estrutura matemática ou cabalística que não permite mudanças e contingências?

Benveniste já demonstrou que a estrutura da língua e a estrutura da sociedade não coincidem. Não há correlação de necessidade entre uma língua histórica e uma sociedade histórica, por exemplo entre a estrutura da língua francesa e a estrutura da sociedade francesa em 1940. Mas num nível fundamental, língua e sociedade são realidades inconscientes que representam o meio natural e a expressão natural, o espaço e o dizer idealizados como origem, sem os quais nada poderia existir. As duas são sempre herdadas e não se imagina que tenha podido existir um começo. E nenhuma delas pode ser mudada pela vontade dos homens. O que os homens vêem e podem mudar através da história são as instituições, mas não o princípio da sociedade que é suporte e condição da vida coletiva e individual. Da mesma maneira, o que muda na língua, o que os homens podem mudar, não é nunca seu sistema fundamental, mas as designações, que se multiplicam, se substituem e são, de certa forma, a realização de um desejo (BENVENISTE, 1970, p.96). As relações entre língua e sociedade, portanto, não são de natureza estrutural, tipológica ou histórica (genética). A língua e a sociedade se elaboram pelo mesmo processo: “o esforço de produzir meios de subsistência, transformar a natureza e multiplicar os instrumentos" (p.97).

Parte da obra de Perec pode ser percebida como "o testemunho 'jura dizer a verdade', promete a sua veracidade ficcional. Mas aqui mesmo onde ela não cede ao perjúrio, a atestação não pode não manter uma agitada cumplicidade com a possibilidade, ao menos, da ficção" (DERRIDA, 1998, p.1). Tudo é ficção. Tudo é autobiográfico. Tudo é estrutural. Tudo é sociológico. E tudo é, conjecturamos, testemunhal e discutível. O testemunho de Perec se torna, demeure, de forma lenta e peculiar e através das contraintes dá o seu testemunho do sofrimento que a Shoab o fez passar. A contrainte mostra o caos e a desordem, mas também a tentativa do controle, de relatar a verdade, de testemunhar sua própria vida e suas lembranças escurecidas pelo tempo e pela dor. Assim escreve Magné sobre a contrainte: 


\begin{abstract}
Mas, se tratando de Perec, o palíndromo permite uma leitura de duplo sentido, exibe uma dupla escritura, conflitante, onde a orientação direita esquerda se encontra recoberta, mascarada, dominada pela existência do texto padrão, como na escritura judaica em Perec, rebaixada ao nível de escritura jamais esquecida, mas, pior ainda, jamais sabida: "Eu não falo a língua que meus pais falavam”. Desta língua ausente, o palíndromo é o traço e a memória. Não surpreende a sua onipresença na obra perecquiana (MAGNÉ, 1999, p.84).
\end{abstract}

O que resta e o que aparece em Perec é a impossibilidade e a sua tentativa de controlar, classificar e simbolizar os limites, como acontece com "os poetas - as testemunhas - que fundam a língua como o que resta, o que sobrevive em ato à possibilidade - de falar. [...] Não enunciável, não arquivável é a língua na qual o autor consegue dar testemunho de sua incapacidade de falar" (HEIDEGGER apud GAGNEBIN, 2008, p.11). Assim como o nazismo estabelece uma 'ordem' tão rígida quanto aleatória, Perec constrói sua literatura da forma mais rígida e mais contingente possível, se escondendo na própria letra e em seus jogos. Além disso, Perec descreve através da literatura "a veracidade biográfica ou autobiográfica de um testemunho que fala dele próprio e pretende recontar não somente sua vida, mas sua morte, sua quase ressurreição, uma forma de Paixão - aos limites da literatura" (DERRIDA, 2008, p.11).

Aqui a teoria freudiana sobre as brincadeiras infantis pode novamente dar sua contribuição, desde que pensada mais complexamente do que em seus textos iniciais quando a brincadeira se sustenta quase inteiramente no princípio do prazer e em seu desdobramento na fantasia. Em 1920, no texto "Além do princípio de prazer", Freud (1920/1996) caminha na direção de algum funcionamento mental que não apenas independa, mas que é mesmo mais fundamental e primordial do que o princípio de prazer com sua variação em princípio de realidade. É nesse texto que podemos encontrar a análise freudiana do jogo do fort da já citado acima. Aqui, a fantasia não é tão evidente quanto nas brincadeiras comparadas à arte. Se, em um primeiro passo, a análise de Freud o conduziu a comparar o brincar com a atividade artística, a comparação agora é de ordem muito menos romântica. A comparação que Freud estabelece em 1920 para o brincar não é com o artista nem com o espectador da arte, mas com os chamados neuróticos de guerra, que na classificação atual da medicina se encaixam naquilo que ficou conhecido como Transtorno de Estresse Pós-Traumático.

A ligação das brincadeiras infantis às neuroses de guerra, que muito se relacionam aos aspectos biográficos de Perec, se deve à interpretação freudiana da célebre brincadeira de seu neto. Em um primeiro momento, a criança brincava de jogar os mais variados objetos para longe de sua vista ao mesmo tempo 
em que emitia um som semelhante ao alemão fort. Certo dia a criança encontra um carretel que a permite completar a brincadeira e assim não apenas lança o objeto, perdendo-o, como o faz aparecer novamente puxando o barbante, quando emite um som semelhante à palavra alemã da. A interpretação de Freud é de que o menino revivia nesse jogo a saída da mãe, ou seja, a perda do objeto mãe. Considerando que a primeira parte do jogo independia da segunda, ou seja, que houve uma época em que ele apenas fazia propositalmente perder o objeto, Freud supõe que existe nesse jogo algo análogo às neuroses de guerra. Se nas neuroses de guerra o que é repetido é a situação traumática da guerra, os sonhos com explosivos, a alucinose com os barulhos de tiros entre outras lembranças, no jogo da criança o que é repetido é a perda do objeto materno. Pode-se julgar exagerado comparar a ansiedade causada pelo perigo iminente da morte com a perda temporária da mãe. Mas em psicanálise isso se esclarece quando lembramos que, como afirma Freud (1926/1996), um dos primeiros sinais de ansiedade apresentados pelas crianças é o colo de um estranho, ou seja, a perda do objeto materno (ou familiar). Perec sempre recupera e perde as suas lembranças de infância.

A conclusão a que essa discussão conduzirá é bem conhecida: a elaboração da compulsão à repetição, e, através dela, da Pulsão de Morte. Isso significa que existe uma tendência mais primitiva no aparelho psíquico do que o princípio do prazer e que independe dele. Ou seja, mais do que buscar o prazer, nosso aparelho psíquico busca a repetição, ele busca voltar a um estado anterior de coisas, busca repetir o ocorrido. Freud encontra vários exemplos na natureza que indicam uma tendência universal a esse retorno, desde as migrações dos pássaros e a piracema dos peixes até mesmo o destino de todo ser vivo à morte que nada mais é do que o retorno ao inanimado anterior à vida. A compulsão à repetição, não necessariamente se opõe ao princípio do prazer, pelo contrário, pode muitas vezes servir a ele, já que o prazer é a redução da tensão psíquica e a repetição pode conduzir nossa mente a um estado anterior de menor tensão. Essas conclusões fazem Freud dar outros rumos à sua teoria, mas de maneira alguma abandonar o princípio de prazer e de realidade. Ele apenas reconhece que há algo mais fundamental do que eles e que é nesse algo que podemos buscar alguma elucidação tanto para os sonhos dos neuróticos de guerra que repetem uma situação de desprazer quanto para a brincadeira da criança que repete a perda do objeto.

Isso se dá porque Freud reconhece nessas repetições dolorosas a tendência do organismo em dominar, vinculando as energias não vinculadas na mente. Em uma linguagem lacaniana, que apresenta certa crítica a essa ideia do domínio, seria adequado dizer que a perda do objeto ou o perigo iminente de morte na guerra aparecem como real demais, algo inassimilável 
pelo significante. Esse real resiste a ser simbolizado pela criança, por sua rasa imersão no universo simbólico, assim como resiste no neurótico de guerra, pela impossibilidade de o ser humano representar o real da própria morte. Como ressalta Maria Rita de Oliveira Guimarães,

O inassimilável é algo que não passa à representação, ou, dito de outra maneira, não cessa de não se inscrever. Isso importa no contexto da clínica. Não é simplesmente que não se inscreva, mas que sendo o que não cessa de não se inscrever, é causa de novas transcrições. $(2007$, p.3).

Isso que não cessa de não se inscrever, Lacan, no livro 11 de seu Seminário, chama, tomando a palavra emprestada de Aristóteles, de tykhé, em contraponto ao automaton, que é o que Lacan designa por "insistência dos signos aos quais nos vemos comandados pelo princípio do prazer" (LACAN, 1964/2008, p.59). Tykhé, portanto, é o encontro do real, e o real é o que vige sempre atrás do automaton. Não que automaton não seja uma repetição, ele o é, mas não está além do princípio do prazer. O que extrapola esse princípio é o trauma, é o encontro do real, do inassimilável, que não deixa nunca de não se inscrever. Na visão crítica de Lacan, é essa falha na inscrição que mais importa quando Freud descreve a repetição para além do princípio do prazer. O que se repete é a não inscrição do real, o inassimilável do trauma.

Se a ausência da mãe, por exemplo de Perec, é vivida como uma perda do objeto, esse será o seu trauma, a falta, que não cessará de não se inscrever no jogo do carretel. Para Lacan (1964/2008), exercer o papel ativo no desaparecimento do objeto (que representa a mãe) é secundário, o principal da brincadeira do fort da é a superação da divisão do sujeito. Não se trata da repetição da necessidade, que se converteria em pedido do retorno da mãe, isso, para Lacan, se manifestaria por um grito. Trata-se da clivagem do próprio sujeito, sua castração: “...a automutilação a partir da qual a ordem da significância vai se por em perspectiva". (LACAN, 1964/2008, p.66). Assim, o carretel, na análise lacaniana: "...é alguma coisinha do sujeito que se destaca embora ainda sendo bem dele, que ele segura" (1964/2008, p.66). Essa coisinha que se destaca é o que no estudo de Lacan conhecemos como objeto pequeno $a$. Será, portanto, que a busca de Perec é a busca pelo objeto perdido? E a utilização dos jogos é uma forma de esconder e / ou enunciar essa perda?

Retornando ao percurso freudiano sobre a brincadeira infantil, o que percebemos é que, mesmo em sua análise sobre o fort $/ d a$, Freud não abandona sua primeira definição do brincar e, depois de dizer que “.... em suas brincadeiras as crianças repetem tudo o que lhes causou uma grande impressão na vida real...", afirma que “... é óbvio que todas as suas brincadeiras são 
influenciadas por um desejo que as domina o tempo todo: o desejo de crescer e poder fazer o que as pessoas crescidas fazem." (FREUD, 1920/1996, p.27). Essa afirmação é feita no início do texto e será mantida até o final da obra freudiana, porém, com um acréscimo importante. Tal acréscimo só virá depois do autor ter começado a avançar no conceito de compulsão à repetição e então demonstrar como a compulsão à repetição entra na brincadeira infantil, muitas vezes sem se opor ao princípio do prazer, o que talvez não possa ser dito das neuroses de guerra. Para o autor, “... as crianças repetem experiências desagradáveis pela razão adicional de poderem dominar uma impressão poderosa...” (FREUD, 1920/1996, p.46). A via escolhida por Perec para tratar dessas questões é a literatura sob restrições. Uma literatura obsessiva, compulsiva que tenta esgotar todas as possibilidades a partir das regras e jogos conhecidos.

Vale à pena retomar, nesse ponto, a já referida crítica que Lacan faz a essa afirmação em 1964, quando assinala que: "Dizer que se trata simplesmente para o sujeito de se instituir numa função de domínio é uma tolice" (LACAN, 1964/2008, 232). A crítica novamente se sustenta na operação lacaniana citada acima e que Miller (2005) designa como sendo a clivagem da repetição, o que a distingue em dois níveis: tykhé e automaton. Dizer que a repetição é puro domínio, é acreditar:

...que tudo o que fosse da ordem do natural, dado no começo, real, passaria ao simbólico, sem deixar resto. O Seminário 11 assinala que a relação da repetição com o objeto não é a de uma simples anulação. (MILLER, 2005, p.167).

A repetição a que Lacan se refere, portanto, vai ao encontro de um real, e o real se relacionará com o trauma, que Lacan transforma no “... conceito freudiano do inassimilável pelo significante...” (MILLER, 2005, p.167), e que é o motor da repetição a partir do Seminário 11. Se o trauma é o inassimilável, ele não pode ser dominado, ele sempre deixa um resto, e é esse resto que motiva a repetição. A repetição, por sua vez, nunca dará conta desse prometido domínio, o que não significa que nada pode ser transcrito. Nessa perspectiva, a compulsão à repetição aparece na brincadeira infantil tanto enquanto determinada pelo encontro com o real, tykhé, quanto determinada pela insistência dos signos, automaton, princípio do prazer. É nesse sentido que podemos dizer que a obra de Perec está no litoral entre o simbólico da insistência dos signos e o real, enquanto insistência do objeto perdido, do impossível de simbolizar. Novamente Perec se porta como uma criança e converge a repetição do além do princípio do prazer e a satisfação do princípio do prazer:

No caso da brincadeira das crianças, já demos ênfase às outras maneiras pelas quais o surgimento da compulsão 
pode ser interpretado; aqui, a compulsão à repetição e a satisfação instintual que é imediatamente agradável, parecem convergir em associação íntima. (FREUD, 1920/1996, 33).

A repetição obsessiva de Perec pelos jogos literários de esconde-esconde pode ser pensada como sua compulsão, sua busca pelo além do princípio do prazer, pela tentativa de escrever o que não cessa de não se escrever, por mais que se escreva. Podemos supor que Perec tenta escrever a perda de seus parentes desaparecidos através de faltas e restrições enunciativas, tal qual a criança tenta escrever a perda da mãe através do carretel.

Para Freud (1926/1996), a ansiedade é incorporada na mente através de experiências anteriores, e nesse sentido não há uma experiência mais primitiva de intensa ansiedade do que o nascimento, que é, em outros termos, uma experiência de perda, de perda da mãe e do conforto da vida uterina. Mas se a ansiedade aparece toda vez que a criança supõe a repetição da experiência traumática (e as primeiras experiências traumáticas são sempre experiências que lançam o sujeito no desamparo do mundo externo), toda vez que ela for abandonada por um adulto, ela dará um sinal da antecipação do perigo que acredita correr. A criança, portanto, sempre que abandonada revive a situação de sair do conforto da presença do objeto e pressente uma insegurança dando sinais de ansiedade, ainda que nem sempre sua insegurança seja justificada. Os perigos estão, assim, relacionados ao desamparo e à perda do objeto, e perda do objeto, em psicanálise, não tem outro nome senão castração. Estamos de novo no ponto em que Lacan (1964/2008) indica que o carretel é uma "coisinha do sujeito que se destaca". A obsessão em Perec também pode ser pensada a partir dessa coisinha que se destaca e que retorna a cada escrita do autor.

O desamparo humano (talvez intensificado na orfandade em Perec), que se revela na dependência do bebê a seus primeiros objetos, explica os medos mais convencionais das crianças como ficar sozinho, ficar no escuro ou ser entregue a um estranho - situações que repetem a perda do objeto. Toda essa digressão nos reconduz à brincadeira em geral e à brincadeira de esconder em particular, pois o que é a brincadeira do esconder, seja o carretel ou seja o rosto, senão uma repetição do trauma de perder o objeto? Temos então que antes de participar da brincadeira do esconder, a criança vivia a separação do objeto como uma experiência traumática de abandono e desamparo. Freud (1926/1996) ressalta que como a criança ainda não sabe distinguir a ausência temporária da perda permanente, por exemplo da morte, ela vive cada experiência de separação como uma morte. É preciso então que repetidas experiências de afastamento ocorram para que a criança perceba que a ausência da mãe pode ser acompanhada de seu reaparecimento. As mães parecem se dar conta de parte desse processo, uma 
vez que muito costumeiramente elas consolam seus filhos com palavras do tipo: "Mamãe está aqui, não precisa chorar, etc.". Nesse momento, cabe trazer outra referência freudiana importante para a teoria das brincadeiras de esconder: "A mãe encoraja esse conhecimento [o conhecimento de que o desaparecimento não é permanente], que é tão vital para a criança, fazendo aquela brincadeira tão conhecida de esconder dela o rosto com as mãos e depois, para sua alegria, de descobri-lo de novo" (FREUD, 1926/1996, p.165).

Para fins de resumo da situação apresentada, e já cientes da crítica lacaniana quanto à importância do domínio das experiências psíquicas, podemos retomar as palavras proferidas por Freud algumas páginas antes de sua referência à brincadeira do puti para depois retomarmos com mais detalhes a investigação dos jogos de esconder:

A ansiedade é a reação original ao desamparo no trauma, sendo reproduzida depois da situação de perigo como um sinal em busca de ajuda. $\mathrm{O}$ ego, que experimentou o trauma passivamente, agora o repete ativamente, em versão enfraquecida, na esperança de ser ele próprio capaz de dirigir seu curso. É certo que as crianças se comportam dessa maneira em relação a toda impressão aflitiva que recebem, reproduzindo-a em suas brincadeiras. Ao passarem assim da passividade para a atividade tentam dominar suas experiências psiquicamente. (FREUD, 1926/1996, p.162).

\section{Enunciação e esconde-esconde}

Tendo dito já muita coisa sobre o brincar infantil, sobre as restrições literárias e sobre Perec, e sua relação com a arte e o fantasiar bem como a compulsão à repetição e a ansiedade do trauma, chegamos à conclusão de que além de se apoiar na satisfação do princípio do prazer, reservando um pedaço do eu livre das condições do mundo externo, o texto de Perec também se serve da compulsão à repetição ou do retorno ao estado anterior de coisas.

Comecemos pelo que achamos de mais primitivo em nossas pesquisas e que se relaciona com o brincar de esconder como uma espécie de pré-brincadeira. Referimo-nos à experiência da perda objetal. Isso quer dizer que nem sempre a criança pôde participar do jogo de esconder, pois existia uma época em que ela mesma não se distinguia da mãe e a separação não poderia de maneira alguma ser experimentada como uma brincadeira nem a criança poderia dela retirar prazer. Vimos com Lacan (1964/2008) que a brincadeira do carretel, por exemplo, 
exige uma superação da clivagem do sujeito. Antes de brincar de esconder, a criança tem de ter experimentado a separação da mãe ou do adulto protetor como o avesso do prazer lúdico, um tormento comparável aos traumas de guerras ou a outras situações de perigo de vida. É só depois de verificar que o objeto não faz parte do eu infantil, só depois de destacar essa coisinha que será o objeto $a$, é que ela pode finalmente entrar no jogo e retirar algum prazer disso, pois não duvidamos que um dos principais motivos de toda brincadeira seja retirar alguma cota de prazer. Perec busca se reconciliar com a mãe como uma volta à indissociação perdida, uma referência ao próprio texto onde brincadeira e seriedade caminham juntas.

Vencida essa primeira etapa e preparada para a brincadeira, a criança, desde que auxiliada por um adulto, pode então repetir essa experiência traumática em forma de brincadeira, quem sabe mais tarde em forma de poesia. É importante aqui destacarmos a função da linguagem nesse processo. Dissemos logo no início que a maioria dessas brincadeiras de esconder são acompanhadas de vocalizações paradigmáticas como o fort e o da da brincadeira do neto de Freud. Enunciações como sumiu e achou, vai e vem, e outras, têm uma função psíquica, uma vez que são, em sua maioria, antítese significantes, um S1 e um S2: "Não há fort sem da...” (LACAN, 1964/2008, p.232). Na tradição dos estudos linguísticos, a enunciação é justamente conceituada como um acontecimento, como algo que inaugura um dizer, que sobrepõe a linguagem (já sempre em funcionamento com suas cadeias de significados pairando sob cadeias significantes, sujeitos falantes cindidos e suas histórias) à língua enquanto sistema abstrato e relativamente autônomo. Essa tomada da palavra não é, pois, nunca desvinculada das contraintes desse sistema nem do campo de memória que possibilita que o dizer tenha sentido. A enunciação coloca a língua em funcionamento. Mas o sujeito também acredita agir nesse processo, acredita falar por si só, fantasia ser a origem de seu dizer e não desconfia que suas palavras poderiam ter sido outras. A enunciação está ligada, de certa forma, à repetição, pois imaginariamente o sujeito crê na originalidade de seu dizer e pode-se, ainda, relacionar toda tomada de palavra a um momento único, irrepetível (como no aforismo da filosofia do devir: tudo flui como um rio), mas, por outro lado, nenhum dizer tem sentido se não ressoar de e em outras enunciações, se não for repetição, retomada, redizer. $\mathrm{O}$ fort/da ou o achou das brincadeiras infantis encontram na fala do adulto seu campo de memória, enquanto o esconde-esconde literário de Perec faz bastante sentido em relação à falta de seus pais, à tragicidade dessa perda. Por isso o jogo com a linguagem, com a estrutura, com a letra através dos palíndromos, lipogramas, anagramas. Ainda que, como lembra Lacan, não seja da oposição pura e simples do fort e do da que o jogo retire sua força inaugural - mas sim do carretel enquanto objeto $a$ - essa 
oposição entre os sons emitidos parece não ser gratuita, uma vez que coloca o sujeito entre dois significantes que o auxiliarão rumo à superação da castração.

Se assim realmente for, temos então que a primeira função do brincar não é atender ao desejo de ser adulto, mas de tentar inscrever a falta inassimilável do objeto que não cessa de não se inscrever. É fácil supor, então, que em um primeiro momento a criança talvez esteja mais preocupada em recuperar o objeto escondido do que deixá-lo omisso por muito tempo. Isso porque nessas situações a criança atua de forma passiva e anseia pelo encontro do objeto que se faz desaparecer por iniciativa do adulto, lembrando a célebre frase de Perec sobre o esconde-esconde e seu desejo de ser descoberto e o medo de não o ser.

Essa análise nos conduz a uma pergunta inevitável: quando a criança passa do jogo da repetição do trauma ao jogo fantasioso de ser adulto? Quando a coisa é ludicamente séria ou, simplesmente, seriamente lúdica? Essas formas de jogo coexistem ou passam a existir depois de determinada constituição do eu?

Algumas dessas respostas podem ser procuradas na relação do sujeito com o objeto, que como aprendemos com Freud (1923/1996), pode ser pelo menos de duas ordens: um desejo de ter o objeto e um desejo de ser o objeto, de incorporá-lo. Assim, a criança representaria em suas brincadeiras ambas as situações, uma em que ela repete a perda do objeto e outra em que ela, fantasiosamente, se identifica com o objeto amado adulto, que é uma das formas de se ter o objeto. É nessa falta eterna que encontramos a escrita e os enigmas de Perec. Sua busca pela infância perdida, pelas brincadeiras infantis desaparecidas. Freud (1923/1996) defenderá essa hipótese afirmando que se o Eu se apresentar ao Isso semelhantemente ao objeto perdido, o Isso pode amar o objeto através do amor narcísico que sente pelo Eu. Em outras palavras, se uma criança se assemelha ao adulto, ela pode amar essa parte de si que se parece com esse adulto. Teríamos nessa distinção entre o amor do ter e o amor do ser uma pista de como a criança brinca para representar tanto uma quanto outra situação, ter e ser o objeto (adulto). Já a repetição parece se dever mais à falta do objeto do que ao desejo de tê-lo ou sê-lo. Ou seja, mais pelo vazio do que por sua representação. Por enquanto, apenas sugeriremos que o mesmo motor que move a repetição, aquilo que não cessa de não se inscrever, move também a fantasia presente nos jogos mais elaborados da criança e, também, na escritura de Perec. Como afirma Lacan, “... o real vai do trauma à fantasia...”, já que “... a fantasia nunca é mais do que a tela que dissimula algo de absolutamente primeiro, de determinante na função da repetição" (LACAN, $1964 / 2008$, p.64). Talvez o que possa ser proposto por enquanto, é que o real também vai da brincadeira do esconder à brincadeira do fantasiar (desejo de ser adulto) e das restrições literárias em busca desse real perdido. 


\section{REFERÊNCIAS}

BENVENISTE, Émile. "Estrutura da língua e estrutura da sociedade" e "O aparelho Formal da enunciação". In: Problemas de linguística geral II. Campinas: Pontes, 1989, p. $81-90 /$ p. $93-104$.

BURZIO, Luigi. Italian Syntax: a government and binding approach. Dordrecht: D. Reisel Publishing Company, 1986.

CALVINO, Italo. Porque ler os clássicos. São Paulo: Companhia das Letras, 1993.

Seis propostas para um novo milênio. São Paulo:

Companhia das Letras, 2003.

CASTRO, Maria Fausta Pereira de. "A infância e a aquisição da linguagem". Revista Com Ciência n" 72 Infância, dez. 2005. Disponível em: <http://www.comciencia.br/comciencia/ handler.php?section $=8 \&$ edicao $=5 \&$ id $=35>$.

CIRÍACO, Larissa et CANÇADO, Márcia. "Inacusatividade e inergatividade no PB". Caderno de Estudos Linguísticos, n 46 (2). Campinas: Unicamp, 2004, p. 207-225.

COMPAGNON, Antoine. O trabalho da citação. Belo Horizonte: Ed. UFMG, 1996.

O demônio da teoria. Belo Horizonte: Ed. UFMG, 2006.

DERRIDA, Jacques. Demeure. Paris: Galilée, 1998. - Mal de arquivo: uma impressão freudiana. Rio de Janeiro: Relume Dumará, 2001.

FREUD, Sigmund. (1996) Edição Standard das Obras Psicológicas Completas de Sigmund Freud. Rio de Janeiro: Imago. p.133-146. (1908) "Escritores Criativos e devaneios", v.IX, - (1911) "Formulações sobre os dois princípios de funcionamento mental”, v.XII, p.233-246. p.13-78. (1920) "Além do princípio do prazer", v.XVIII, . (1923) “O Ego e o Id”, v. XIX, p.15-82. . (1926) "Inibições, sintomas e ansiedade", v.XX, p.81-174.

(1942) "Personagens psicopáticos no palco", v.VII, 
p.289-298.

LACAN, Jacques. (2003). "Lituraterra”. In: . Outros escritos. Rio de Janeiro: Jorge Zahar Editor, f. 397. - (1997) O Seminário, livro 7: a ética da psicanálise. Rio de Janeiro: Jorge Zahar Editor, f. 397. - (1964/2008) O Seminário, livro 11: os quatro conceitos fundamentais da psicanálise. Rio de Janeiro: Jorge Zahar Editor, f. 277.

LEMOS, Cláudia Thereza Guimarães de. "Das vicissitudes da fala da criança e de sua investigação". Cadernos de Estudos Linguísticos $n^{\circ} 42$ (1), 2002, 41-69.

MAGNÉ, Bernard. Georges Perec. Paris: Éditions Nathan Université, 1999.

MILLER, Jacques-Allan. (2005) Silet. Rio de Janeiro: Jorge Zahar Editor, f. 334.

PÊCHEUX, Michel. (1975) Semântica e discurso: uma crítica à afirmação do óbvio. Trad. Eni P. Orlandi. Campinas: Ed. Unicamp, 1997.

PEREC, Georges. La disparition. Paris: Denoel, 1969a. - W ou a memória da infância. São Paulo: Companhia das letras, 1995, f. 200. A vida modo de usar. São Paulo: Companhia das Letras, 1989b. . Le Cabier des charges de la Vie mode d'emploi. Paris: C.N.R.S.et Zulma, 1993.

PERLMUTTER, David. "Impersonal passives and the Unaccusative Hypothesis”. Berkeley Linguistics Society 4, 1978, p.157-189.

SELIGMANN-SILVA, Márcio. História Memória Literatura: o testemunho na era das catástrofes. Campinas: Unicamp, 2003. O local da diferença: ensaios sobre memória, arte, literatura e tradução. São Paulo: Editora 34, 2005. 